\title{
JUNIOR SECONDARY SCHOOL STUDENTS' CONCEPTIONS ABOUT PLATE TECTONICS
}

\author{
Reece Mills ${ }^{1}$, Louisa Tomas, and Brian Lewthwaite
}

\begin{abstract}
There are ongoing calls for research that identifies students' conceptions about geographical phenomena. In response, this study investigates junior secondary school students' $(\mathrm{N}=95)$ conceptions about plate tectonics. Student response data was generated from semi-structured interviews-about-instances and a two-tiered multiple-choice test instrument developed and validated by the researchers. There were three main findings: (1) students held many alternative conceptions about plate tectonics, most of which have not been reported in previous research; (2) students' alternative conceptions most commonly concerned the formation of landforms at tectonic plate boundaries; and (3) students were especially confused about the cause of subduction at an oceanic-continental convergent plate boundary. The findings of this study can assist geography teachers and researchers to develop innovative pedagogies that consider students' pre-instructional alternative conceptions and promote conceptual change learning.
\end{abstract}

Keywords: Plate tectonics; geography; alternative conceptions; conceptual change; mixed methods

\section{Introduction}

Until recently, geography education in Australia, where this research was conducted, was integrated into the social sciences curriculum. This meant that social issues were given priority over physical systems and their processes, and preservice teachers received little preparation in teaching physical geography (Stoltman, Lidstone, \& Kidman, 2015). With the introduction of a national curriculum that now includes the mandated study of physical geography in junior secondary school (Australian Curriculum, Assessment and Reporting Authority, 2013), some scholars are concerned that Australian teachers are underprepared to teach physical geography concepts and address students' alternative conceptions in this area (Dawson \& Carson, 2013; Lane, 2009, 2015). Although there is some emerging research on students' preconceptions about physical geography phenomena, little has focused on school students' understanding of plate tectonics. Such understanding is critical to inform geography teachers' instructional decisions, so as to best support students' learning. This paper investigates junior secondary students' preconceptions about plate tectonics, with the aim of using this understanding to promote further research into conceptual change learning in the physical geography discipline. The sections that follow begin by briefly reviewing the literature on conceptual change learning and students' alternative conceptions about plate tectonics, before outlining the research problem and detailing the methodology, including the data sources and approach to data analysis.

\section{Conceptual change learning and students' alternative conceptions about plate tectonics}

Research on conceptual change originates primarily from physics and chemistry education research from the 1970 s onwards. The classical view of conceptual change holds that students' alternative conceptions, which are often incomplete or incorrect, can be better aligned with accepted scientific concepts through instruction (Posner, Strike, Hewson, \& Gertzog, 1982). More recently, however, there are multiple perspectives concerning the nature of conceptual change. One variation on the classical conceptual change model suggests that alternative conceptions arise if students assign concepts to incorrect ontological

${ }^{1}$ Email: Reece.Mills@my.jcu.edu.au 
categories (Chi, Slotta, \& DeLeeuw, 1994). Another variation considers the role of affective factors including motivation, interest and self-efficacy as variables that bring about conceptual change (Pintrich, Marx, \& Boyle, 1993). Finally, some authors have advocated for a multidimensional model, that views conceptual change from epistemological (classical), ontological and affective perspectives (Treagust \& Duit, 2008; Tyson, Venville, Harrison, \& Treagust, 1997).

Learning about Earth's physical processes is particularly suited to a conceptual change approach. Since many of the processes operate on spatial and temporal scales that cannot be observed directly, they are often misunderstood by students (Dodick \& Orion, 2003). Francek (2013) has developed a comprehensive list of school and university students' preconceptions about Earth's structure, historical geology, plate tectonics, earthquakes, volcanoes, rocks and minerals, and weathering and erosion, finding that most alternative conceptions were about plate tectonics. Some examples of the most widely held alternative conceptions about physical geography phenomena include: Earth's crust is several hundred kilometers thick (Libarkin \& Anderson, 2005; Steer, Knight, Owens, \& McConnell, 2005); tectonic plates are underground and are not exposed at the Earth's surface (American Association for the Advancement of Science, 2015); volcanoes are found in places that have high temperatures, like at the equator (Dahl, Anderson, \& Libarkin, 2005); and weathering and erosion are synonymous (King, 2010). Aside from the difficulties that students have comprehending these concepts, they are also frequently misrepresented in textbooks (King, 2010) and popular culture (Barnett et al., 2006).

Although students' preconceptions about plate tectonics are widespread, they have only been investigated in a handful of studies. These studies were predominantly conducted with university students (e.g., Clark, Libarkin, Kortz, \& Jordan, 2011; Smith \& Bermea, 2012) and the authors are only aware of one published study has investigated school students' alternative conceptions about plate tectonics. This study, conducted by Marques and Thompson (1997), reports on Portuguese students' alternative conceptions of continental movement and plate tectonics. Students aged between 16 and 19 years $(\mathrm{N}=270)$ held several alternative conceptions about plate tectonics. The authors illustrated this claim with data collected from students' written responses to open-ended questions. The most common alternative conception, held by $64 \%$ of students, was that tectonic plates are stacked on top of each other, in layers. Students that had this perspective thought that the oldest plates comprised the bottom layers, while the youngest plates comprised the top layers. Twenty-one percent of students incorrectly thought that the coastlines of continents are the edges of tectonic plates, as illustrated by the following comment, "the coastline is a boundary between plates" (Marques \& Thompson, 1997, p. 208). It was suggested that terminology used in science classes that refers to 'two types of plates' - continental and oceanic - might reinforce this alternative conception. Other alternative conceptions arising from their study were: magnetic polar wandering causes the movement of tectonic plates (34\%); tectonic plates move about a center axis (35\%); and the same processes produce both continental and oceanic mountain ranges $(40 \%)$. While these findings suggest that students are confused about plate tectonics, it is clear that, overall, students' preconceptions in this area remain under-researched, which warrants further exploration in other contexts.

\section{Research problem and methods}

In response to calls for more research into students' preconceptions about geographical phenomena (Stoltman et al., 2015), and in light of recent concerns that Australian teachers are underprepared to teach physical geography (Dawson \& Carson, 2013), this study investigates 
Year 9 students' preconceptions about plate tectonics. In doing so, this research will investigate the following questions: What do students understand about plate tectonics?, and What alternative conceptions do students have about plate tectonics?

This study was conducted at a Preparatory to Year 12 College located in South East Queensland, Australia. An exploratory sequential mixed methods design was employed (Creswell, 2015), whereby qualitative and then semi-quantitative data were generated. The participants were Year 9 students (average age 14 years, $\mathrm{N}=95$ ) who had limited prior knowledge about plate tectonics. The students that participated in the study had only completed a brief five-week physical geography unit one year prior to the current study. Interviews were conducted with a sub-sample of 21 students to gain an insight into their preconceptions about plate tectonics, and to inform the development of a two-tiered multiplechoice test instrument. Following this, the test instrument was administered to all 95 students, with the aim of extrapolating the interview findings to a larger sample of students. The approaches to data collection and analysis are detailed in the sections that follow.

\section{Data collection}

An interview-about-instances technique, commonly used to investigate students' preinstructional conceptions, was adapted for use in this study (Osborne \& Gilbert, 1979). In line with how this method has been used in science education, the first author used photographs to prompt students' consideration of particular concepts concerning plate tectonics, and ensured that students voiced aloud the reason for their response. Some of the questions asked at interview were:

- Can you tell me if this is a photograph of a tectonic plate? Why do you think that?

- This is a satellite photograph of the Andes mountain range in South America. Is this a tectonic plate boundary? Why do you think that?

- These photographs were taken in Christchurch, New Zealand, after the earthquake that occurred there in 2011. What do you think caused this earthquake? Why do you think that?

As the interviews were semi-structured, the researcher did not strictly adhere to an interview schedule. Rather, he pursued courses of fruitful dialogue as they arose and sought out opportunities for gaining an in-depth understanding of students' conceptions. Materials were provided for students to sketch their understanding of the concepts, if necessary.

A two-tiered multiple-choice test instrument with nine items was used in the semiquantitative phase of this study. The first tier of each item on the test was a multiple-choice content question. The second tier was a set of possible reasons for the answer given. The reasons consist of the correct answer and any identified alternative conception/s (from student interviews), together with a wrong answer. The design and validation of the test instrument involved three broad tasks (adapted from Treagust, 1988): (1) defining the content to be tested; (2) researching students' alternative conceptions from the literature and by conducting interviews with students; and (3) developing and validating the test instrument. This style of test instrument was chosen because it is more easily administered and scored than most other methods of ascertaining students' understandings. In addition, two-tiered multiple-choice tests overcome the difficulty associated with traditional multiple-choice tests where students are able to guess the correct response. An example item from the test is shown below in Figure 1. 


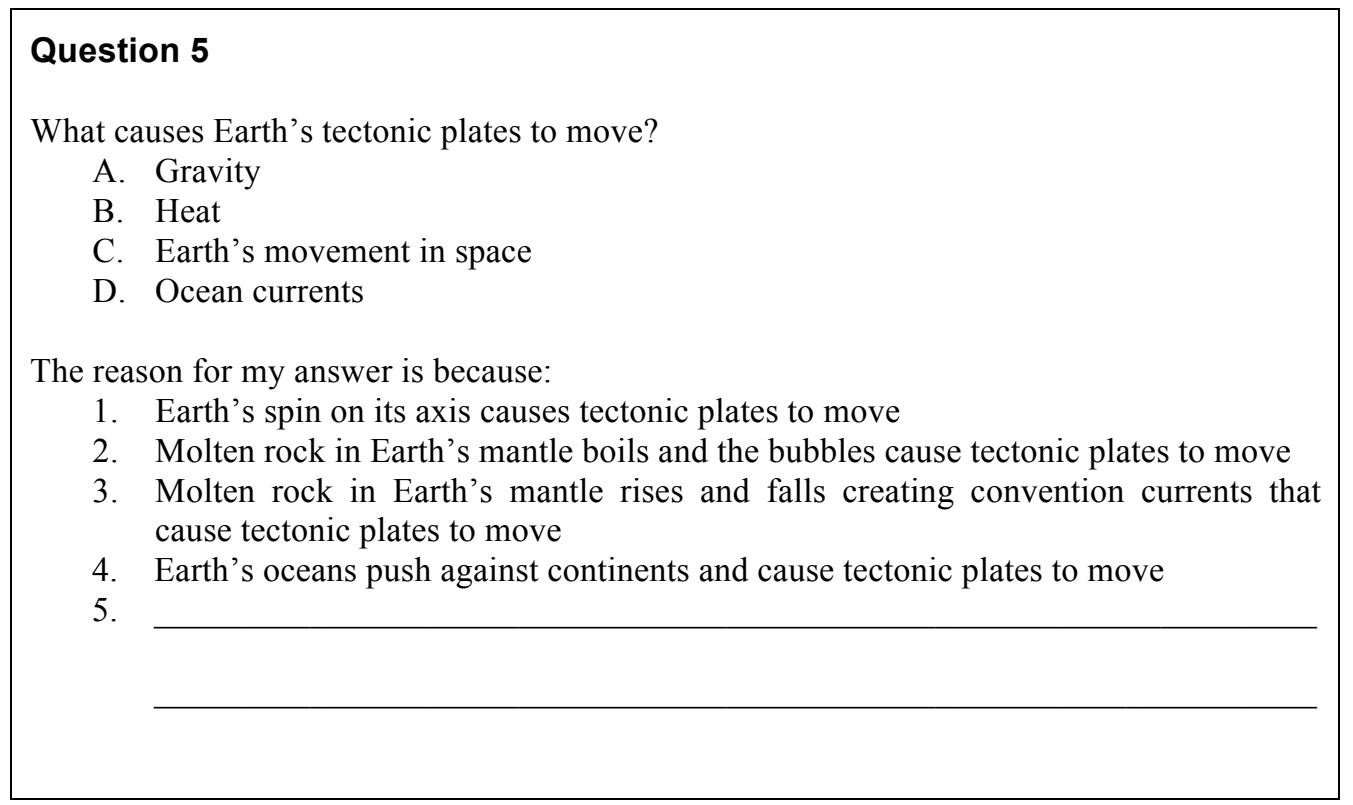

Figure 1. An example item from the two-tiered multiple-choice test instrument.

The trustworthiness of the test instrument was established in multiple ways. First, a panel of three junior secondary science teachers was consulted throughout the entire development process, especially when interpreting the school's enactment of the curriculum in order to write propositional knowledge statements to be tested. Second, a specification grid was designed to ensure that the test instrument fairly covers the propositional knowledge statements and the concepts underlying the topic. Third, Cronbach's alpha coefficient was calculated as 0.53 , which is higher than the 0.50 threshold proposed for multiple-choice tests (Nunally, 1978).

\section{Data analysis}

Interviews with students typically lasted 20 minutes and were audio-recorded and transcribed by the first author for analysis (pseudonyms were used for participants' names). An initial exploratory analysis was carried out by reading all transcripts in their entirety several times to gain a general sense of the data. Following this, the transcripts were divided into segments of text and coded according to their meaning using $N$ Vivo ${ }^{\mathrm{TM}}$ software. An initial framework used for coding was adapted from previous research on students' alternative conceptions of Earth science phenomena. Variations of this framework have been previously been used to analyze school and university students' conceptions of Earth and space science topics including moon phases (Nielsen \& Hoban, 2015; Trundle, Atwood, \& Christopher, 2002) and tides (Ucar, Trundle, \& Krissek, 2011), but not students' conceptions about plate tectonics. This framework categorised students' responses as 'no conception' (e.g., "I don't know"), 'incomplete or alternative conception' (e.g., "Whether it's hot underground will determine whether it's a volcano or mountain"), and 'scientific conception' (e.g., "The lithosphere is broken up into tectonic plates"). In alignment with the research questions, special attention was then given to identifying scientific or alterative conceptions, categorizing them, and calculating their frequency. The first author identified alternative conceptions in discussion with the second and third authors, refining their categorization until they were in agreement.

To analyze the test responses, each item was scored as correct or incorrect (both tiers must be answered correctly for a student to have a correct response) and response frequencies were calculated for each item. 


\section{Findings}

In the following sections, we present evidence to support three findings:

1. Students had many alternative conceptions about plate tectonics, most of which have not been reported in previous research;

2. Students' alternative conceptions were most commonly concerning the formation of landforms at tectonic plate boundaries; and

3. Students were specifically confused about the cause of subduction at an oceaniccontinental convergent plate boundary.

The data that supports these findings is presented in three sections: Students' conceptions about the nature and movement of tectonic plates; Students' conceptions about tectonic plate boundaries; and Students' conceptions about the occurrence of geologic events at tectonic plate boundaries.

\section{Students' conceptions about the nature and movement of tectonic plates}

Interviews with students identified seven alternative conceptions about the nature and movement of tectonic plates (Table 1), five of which have not been reported in previous research. The most common alternative conception held by students was that tectonic plates are underground and are not exposed at the Earth's surface. Often, students thought that tectonic plates are located deep below Earth's crust. The following excerpt from one interview transcript indicates a typical response when students were questioned about their understanding of the nature of tectonic plates:

Researcher: Can you explain to me in your own words what you think a tectonic plate is?

John: $\quad$ A layer of, like, I'm not sure, molten rock maybe? It sits slightly under the surface.

Another widespread alterative conceptions identified in this section concerned the movement of tectonic plates; only one student correctly identified that convection in the mantle is the most commonly accepted cause of tectonic plate movement. These alternative conceptions were not shared between students, however, and students' ideas about the possible driving force of plate movement were varied. Two students believed that gravity somehow caused tectonic plates to move, however, neither student could explain how this occurred. For example:

Researcher: You've mentioned that they move. Do you know what causes tectonic plates to move?

Leanne: Um::: gravity.

Researcher: And how do you think that works?

Leanne: Well, the pull of something. I don't know exactly.

Two students also believed that tectonic plates move due to Earth's movement. One student thought that Earth's orbit around the sun caused tectonic plates to move, while another explained that Earth's spin on its axis caused tectonic plates to move. For example, "I think it's [i.e., tectonic plate movement] to do with the way the Earth moves. The spin it's got affects the plates and which way they move" (Mick). Some students thought that tectonic plates move due to earthquakes or other natural disasters. John, for example, explained "Um::: generally it is natural disasters and stuff like earthquakes ((pause)). I think that's all." Other responses given by students during interview were: ocean currents push against tectonic 
plates and caused them to move; magma boils in Earth's mantle and the bubbles cause tectonic plates to move; and tectonic plates expand, which causes them to move.

Table 1

Students' Alternative Conceptions About the Nature and Movement of Tectonic Plates

\begin{tabular}{lc}
\hline \multicolumn{1}{c}{ Alternative conceptions } & $\begin{array}{c}\text { Frequency } \\
(\boldsymbol{N = 2 1 )}\end{array}$ \\
\hline Tectonic plates are underground; they are not exposed at Earth's surface & 15 \\
Earth's movement in space causes tectonic plates to move & 2 \\
Earthquakes and other natural disasters cause tectonic plates to move* & 2 \\
Gravity causes tectonic plates to move* & 2 \\
Tectonic plates expand, which causes them to move* & 1 \\
Magma boils in Earth's mantle and the bubbles cause tectonic plates to move* & 1 \\
Ocean currents cause tectonic plates to move* & 1
\end{tabular}

Note. Alternative conceptions marked with an * indicate those that have not been reported in previous research.

These findings were supported by the results of the two-tiered multiple-choice test (Table 2). Forty percent of students who completed the test indicated that they believed tectonic plates are located underground, beneath the Earth's crust. Twenty-eight percent of students indicated that Earth's spin on its axis causes tectonic plates to move, and $12 \%$ of students indicated that molten rock in Earth's mantle boils and the bubbles cause tectonic plates to move. Twentythree percent of students correctly identified that the most widely accepted cause of tectonic plate movement is convection in Earth's mantle. Regarding the movement of tectonic plates over time, $35 \%$ of students thought that Earth's continents and ocean basins move a few centimeters over hundreds of years, while $16 \%$ of students thought that this occurs over millions of years. 
Table 2

Students' Alternative Conceptions About Plate Tectonics Identified by the Two-Tiered Multiple-Choice Test Instrument

\begin{tabular}{|c|c|c|}
\hline Item & Alternative conception identified & $\begin{array}{l}\text { Percentage of frequency } \\
\qquad(N=95)\end{array}$ \\
\hline \multirow[t]{2}{*}{1} & Tectonic plate boundaries are found at the edges of continents & 23 \\
\hline & Tectonic plate boundaries are found at the equator & 14 \\
\hline \multirow[t]{2}{*}{2} & $\begin{array}{l}\text { When two continental tectonic plates push together, both plates are } \\
\text { pushed upward to form volcanoes }\end{array}$ & 59 \\
\hline & $\begin{array}{l}\text { Volcanoes are located in places that have a high temperature, like at } \\
\text { the equator }\end{array}$ & 14 \\
\hline \multirow[t]{2}{*}{3} & $\begin{array}{l}\text { Mountains are only formed when the edges of two tectonic plates } \\
\text { are pushed upward }\end{array}$ & 47 \\
\hline & $\begin{array}{l}\text { Mountains are only formed when the edge of one tectonic plate is } \\
\text { pushed upward, and one tectonic plate is pushed downward }\end{array}$ & 17 \\
\hline 4 & $\begin{array}{l}\text { Earth's tectonic plates are located deep within the Earth and are not } \\
\text { exposed at the surface }\end{array}$ & 40 \\
\hline \multirow[t]{2}{*}{5} & Earth's spin on its axis causes tectonic plates to move & 28 \\
\hline & $\begin{array}{l}\text { Molten rock in Earth's mantle boils and the bubbles causes tectonic } \\
\text { plates to move }\end{array}$ & 12 \\
\hline \multirow[t]{2}{*}{6} & $\begin{array}{l}\text { Earth's continents and ocean basins move a few centimeters over } \\
\text { hundreds of years }\end{array}$ & 35 \\
\hline & $\begin{array}{l}\text { Earth's continents and ocean basins move a few centimeters over } \\
\text { millions of years }\end{array}$ & 16 \\
\hline \multirow[t]{3}{*}{7} & $\begin{array}{l}\text { When two tectonic plates push together for millions of years the } \\
\text { larger tectonic plate is pushed upward }\end{array}$ & 26 \\
\hline & $\begin{array}{l}\text { When two tectonic plates push together for millions of years the } \\
\text { tectonic plate that is positioned the highest is pushed upward }\end{array}$ & 23 \\
\hline & $\begin{array}{l}\text { When two tectonic plates push together for millions of years the } \\
\text { faster moving tectonic plate is pushed upward }\end{array}$ & 20 \\
\hline \multirow[t]{3}{*}{8} & When two tectonic plates separate, an empty gap forms & 37 \\
\hline & $\begin{array}{l}\text { When two tectonic plates separate, loose rock fills the gap that } \\
\text { forms between them }\end{array}$ & 21 \\
\hline & A trench forms when oceanic crust material separates & 18 \\
\hline \multirow[t]{3}{*}{9} & Earthquakes occur when two tectonic plates rub together & 41 \\
\hline & $\begin{array}{l}\text { Earthquakes occur at plate boundaries when two tectonic plates } \\
\text { crash together }\end{array}$ & 32 \\
\hline & $\begin{array}{l}\text { Earthquakes occur at plate boundaries when two tectonic plates } \\
\text { suddenly move apart }\end{array}$ & 21 \\
\hline
\end{tabular}

Note. Alternative conceptions were held by $>10 \%$ of students.

\section{Students' conceptions about tectonic plate boundaries}

Students held a range of beliefs about the nature of tectonic plate boundaries. Four alternative conceptions arose from interviews with students (Table 3). Three students thought that tectonic plate boundaries are located at the edges of countries or entire continents. For example: 
Researcher This is a satellite photograph of the Andes, which is a mountain range in South America. Is this a tectonic plate boundary?

Angela Yes, because it's bordering the ocean.

Researcher Do all plate boundaries border the ocean?

Angela Yes. It's the edge of the country, or continent, or whatever you call it.

One student thought that tectonic plate boundaries were located at the equator: “... tectonic plate boundaries are located in those areas where... They are not usually directly on the equator, they're usually around the equator, I'm pretty sure" (Lisa).

Students were particularly confused about interactions between tectonic plates; specifically, processes that occur at an oceanic-continental convergent plate boundary. No students could identify that the difference in density and thickness between oceanic and continental tectonic plate material is the cause of subduction at this type of plate boundary. At interview, more than half the students thought that the size, rate of movement, and/or relative position of a tectonic plate at a convergent plate boundary influenced its interaction with another plate. For instance, when Mick was shown the same satellite photograph of the Andes, he thought that it represented a tectonic plate boundary in which the smaller tectonic plate was pushed upward to form a mountain range: "Yeah I do believe that one of them, I believe it was that side ((points)), was smaller than the other and pushed itself up and created the mountains all the way across." The same student also believed that the relative position of a tectonic plate influenced the subduction process at an oceanic-continental convergent plate boundary:

Researcher Do you think it's just the size of the tectonic plate that influences whether it goes above or below?

Mick Also the position it's in. Because this side might be bigger ((points)) but the other side could just be higher so it just pushed itself over.

The results from the test instrument provide further evidence that students were particularly confused about tectonic plate boundaries. Most notably, 69\% of students indicated that when two tectonic plates push together the size, speed, and/or relative position of the plates determines how they interact. Eighteen percent of students correctly identified that the difference in density between continental and oceanic plate material is the primary factor that influences this process.

Table 3

Students' Alternative Conceptions About Tectonic Plate Boundaries

\begin{tabular}{lc}
\multicolumn{1}{c}{ Alternative conceptions } & $\begin{array}{c}\text { Frequency } \\
(\mathbf{N = 2 1})\end{array}$ \\
\hline $\begin{array}{l}\text { When two tectonic plates push together the size, speed, and/or relative position of the } \\
\text { plates determines how they interact* }\end{array}$ & 12 \\
Tectonic plate boundaries are located at the edge of countries & 3 \\
When two tectonic plates move apart an empty gap forms between them & 1 \\
Tectonic plate boundaries are located at the equator* & 1 \\
\hline
\end{tabular}

Note. Alternative conceptions marked with an * indicate those that have not been reported in previous research. 


\section{Students' conceptions about the occurrence of geological events at tectonic plate boundaries}

Students' conceptions in this category were about the occurrence of geological events at tectonic plate boundaries: the formation of mountains, the formation of volcanoes, and the cause of earthquakes. Alternative conceptions about landform formation were most widespread (Table 4). The data pertaining to each of these geological events is presented below.

Table 4

Students' Alternative Conceptions About the Occurrence of Geological Events at Tectonic Plate Boundaries

\section{Alternative conceptions}

Frequency

$(N=\mathbf{2 1})$

Earthquakes occur when the edges of two tectonic plates suddenly crash together*
Mountains are only formed when the edge of one tectonic plate is pushed upward *
All mountains are volcanoes
Volcanoes are located in places that have high temperatures, like near the equator
When two tectonic plates push together and both plates have continental plate material at
their edge, both plates are pushed upward to form a volcano*
A canyon is formed when two continental plates push together *
A trench is formed when two oceanic plates move apart $*$
When two tectonic plates push together and continental material is at the edge of both
plates, one plate is pushed upward to form mountains *
A trench is formed when the edges of two oceanic plates are pushed upward *
Mountains are formed by wind erosion *
Mountains are only formed when the edges of two tectonic plates are pushed upward $*$
Mountains form by pieces of rock piling up

Note. Alternative conceptions marked with an * indicate those that have not been reported in previous research.

\section{Formation of mountains}

The most common idea was that mountains are only formed when the edge of one tectonic plate is pushed upward. Five students explained that this happened when continental plate material is at the edge of both tectonic plates, such at the boundary between the Indian and Eurasian plates where the Himalayas formed. For example:

Nicole The way that mountains are formed are when two plates push together and eventually they'll just be pushing and pushing and pushing until one sort of pops over and then that can sometimes create a volcano, a mountain, and so forth.

Researcher So how do you think these mountains were formed ((points to Himalayas))?

Nicole By tectonic plates pushing together and one, sort of... Just pushing together and one going up.

One student thought that mountains are only formed when the edges of two tectonic plates are pushed upward: "Well I'm thinking that they (the tectonic plates) have collided together and both of them have gone up because that's how mountains are formed" (Mick). Other incorrect 
ideas were: mountains are formed when pieces of rock pile up; mountains are formed by wind erosion; and all mountains are volcanoes.

Again, the results of the test support these findings. The results show that $47 \%$ of the students that completed the test think that mountains are only formed when the edges of two tectonic plates are pushed upward. Seventeen percent of students indicated that mountains are only formed when the edge of one tectonic plate is pushed upward. Twenty-three percent of students correctly identified that mountains can be formed when both these scenarios occur.

\section{Formation of volcanoes}

The most common alternative conception, held by three students at interview, was that volcanoes are located in places that have a high temperature, like at the equator. This belief was held by $59 \%$ of students who completed the test. Two students at interview thought that volcanoes are formed when two tectonic plates that have continental plate material at their edge are both pushed upward. Fourteen percent of students selected this response on the test. Only $10 \%$ of students completing the test knew how volcanoes form at tectonic plate boundaries.

\section{Cause of earthquakes}

Eleven students had an incorrect understanding about the cause of earthquakes at interview, believing that earthquakes occur when two tectonic plates crash together at a convergent plate boundary. This finding is supported by the results of the test instrument, which show that $32 \%$ of the broader sample of students held this belief. Other alternative conceptions that arose from the results of the test instrument include the belief that earthquakes are caused by tectonic plates suddenly moving apart $(21 \%)$ and that earthquakes are caused by tectonic plates rubbing together $(41 \%)$. Only two students $(2 \%)$ indicated on the test that earthquakes occur along breaks in rock where pressure builds up until one side moves relative to the other side.

\section{Discussion}

This study aimed to determine what students understand about plate tectonics, and what alternative conceptions they have about the topic. In regard to the first research question, students had a limited understanding of plate tectonics. At interview, no students had a scientifically accurate understanding about the nature and movement of tectonic plates, tectonic plate boundaries, or the occurrence of geologic events at tectonic plate boundaries. The questionnaire confirmed that students are confused about plate tectonics. Although 53\% of students knew that the outer layer of the Earth consists of separate tectonic plates, only $23 \%$ of students correctly identified that the most widely accepted cause of tectonic plate movement is convection in Earth's mantle. Fewer students $(18 \%)$ understood how tectonic plates interact at plate boundaries, and fewer still understood the formation of mountains $(23 \%)$ and volcanoes $(10 \%)$, and the occurrence of earthquakes $(2 \%)$.

Students had many alternative conceptions about plate tectonics. In regard to the second research question, students' alternative conceptions most commonly concerned the formation of landforms at tectonic plate boundaries. This is evidenced by the large proportion of students believing that: mountains are only formed when the edges of two tectonic plates are pushed upward (47\%); volcanoes occur in places that have high temperatures $(59 \%)$; and earthquakes occur when two tectonic plates crash together. Most students were specifically confused about the differences between continental and oceanic plate material and therefore the cause of subduction at an oceanic-continental convergent plate boundary. A combined 
$69 \%$ of students indicated that when two tectonic plates push together the size, speed, and/or relative position of the plates determines how they interact.

Many of students' alterative conceptions arising from this study have not been reported in previous research. It is possible that the first author's background as a senior secondary Earth science teacher has meant that he was able to gain a more in-depth insight into students' conceptions at interview. The Australian context of the research may also play a role in the novel findings, as previous research reporting school and university students' conceptions of plate tectonics originates from elsewhere (e.g., Clark et al., 2011; Marques \& Thompson, 1997; Smith \& Bermea, 2012).

\section{Implications for geography teachers}

To effectively implement conceptual change instructional approaches in geography, teachers must first be aware of students' pre-instructional alternative conceptions. Teachers need a repertoire of formative assessment strategies for diagnosing students' alternative conceptions. Some suggestions on how this might be achieved include the use of concept mapping, word associations and drawings (Ozturk \& Alkis, 2010). Another possibility is the use of a twotiered multiple-choice test, such as the instrument developed and implemented in the current study.

Addressing students' alternative conceptions, such as those that have arisen from the current study, presents the next challenge for geography teachers. Effective instructional interventions that are specifically designed to rectify students' alternative conceptions have been developed and used widely across the science disciplines. Those adopted in the Earth science discipline may prove to be fruitful in a physical geography context. Conceptual change instructional approaches in Earth science, for instance, have developed over the past 25 years from the natural observation of phenomena and the use of physical models, to the use of computer simulations as technological advances and access to technology increase (Mills, Tomas, \& Lewthwaite, in press). The latter approaches could be trialed in physical geography, when temporal and spatial scales prevent phenomena from being observed directly.

The findings from this study suggest that conceptual change instructional approaches are required to address certain concepts and processes related to plate tectonics. Students' widespread alternative conceptions about the formation of landforms at tectonic plate boundaries suggest that a targeted conceptual change approach may be required to teach the relevant processes. Similarly, students' distinct lack of understanding about the cause of subduction at an oceanic-continental plate boundary demonstrates that this is another process that requires additional or special attention.

\section{Recommendations for future research}

As mentioned earlier, there are few published studies that explore school students' alternative conceptions of geographical phenomena, and even fewer that advocate for an evidence-based conceptual change approach for learning in geography. Continued research into students' conceptions of geographical phenomena, including how scientific and alternative conceptions may arise, is required in order to develop conceptual change instructional approaches. Research of this nature can inform professional development for teachers in effective implementation of geography curricula and evaluate instructional approaches. Some examples of how this paucity of research is being addressed include the identification of students' alternative conceptions about groundwater (Reinfried, 2006), cyclones (Lane \& Coutts, 2012) and desertification (Schubert, 2014). 
Research on teachers' conceptions of geographical phenomena is also required so that common alternative conceptions can be addressed through professional development. This is especially important given that teachers can be a source of students' alternative conceptions (King, 2000), and some Australian geography teachers do not see value in extensive and indepth content knowledge (Lane, 2015). An example of recent research that meets this aim investigated geography teachers' understanding of cyclones (Lane, 2011). Of concern is that teachers held a range of alternative conceptions and lacked knowledge of underlying scientific concepts. Research of this nature is especially warranted in the physical geography discipline, given that many Australian geography teachers are underprepared to teach in this area due to a lack of appropriate training (Dawson \& Carson, 2013; Stoltman et al., 2015).

Strengthening the internal reliability of the test instrument used in this study, as measured by Cronbach's alpha coefficient, is another direction for future research. This could be achieved by adding items of a similar quality to the test instrument. The authors have calculated that 21 items (i.e., an additional 11 items) would be needed for an even more acceptable internal reliability of 0.60 (Nunally, 1978). A strengthened version of the test instrument could be used in future research to diagnose students' alternative conceptions across multiple year levels or evaluate the effectiveness of a targeted intervention.

\section{Concluding remarks}

This study illuminates further secondary school students' preconceptions of geographical phenomena; specifically, of plate tectonics. It was found that students had many alternative conceptions that seemed to persist from prior instruction. This finding supports the previously mentioned concern that some Australian teachers are uninformed and ill equipped to effectively teach physical geography. Amidst recently mandated physical geography units in Australian secondary schools, further research into students' preconceptions about Earth's physical processes is desperately needed. Likewise, research on conceptual change instructional approaches designed to address students' alternative conceptions is particularly warranted. The first author's ongoing research informed by this study now seeks to investigate the use of student-generated animation to promote junior secondary school students' scientific conceptions of tectonic plate boundaries. In this process, students will manipulate and photograph a range of materials to produce and narrate a slowmation that explains the processes that occur at tectonic plate boundaries. A version of the two-tiered multiple-choice test used in the current study will be administered to students before and after they construct their animation. As such, this study will respond to the concerns about the lack of research on students' geography preconceptions and evidence-based conceptual change instructional approaches.

\section{Acknowledgements}

We would like to thank to the Queensland College of Teachers for the provision of a grant that enabled the first author to present this research at the Australasian Science Education Research Association 2015 conference. We would also like to thank the reviewers for their thoughtful suggestions to improve the quality of our initial manuscript. 


\section{References}

American Association for the Advancement of Science. (2015). Topic: Plate tectonics. Retrieved February 28, 2015, from: http://assessment.aaas.org/topics/PT\#/

Australian Curriculum, Assessment, and Reporting Authority. (2013). 7-10 Geography. Retrieved February 3, 2016, from: http://www.australiancurriculum.edu.au/humanities-and-socialsciences/geography/curriculum/f-10?layout=1

Barnett, M., Wagner, H., Gatling, A., Anderson, J., Houle, M., \& Kafka, A. (2006). The impact of science fiction film on student understanding of science. Journal of Science Education and Technology, 15(2), 179-191.

Chi, M., Slotta, J., \& De Leeuw, N. (1994). From things to processes: A theory of conceptual change for learning science concepts. Learning and Instruction, 4(1), 27-43.

Clark, S., Libarkin, J., Kortz, K., \& Jordan, S. (2011). Alternative conceptions of plate tectonics held by nonscience undergraduates. Journal of Geoscience Education, 59, 251-262.

Creswell, J. (2015). A concise introduction to mixed methods research. Thousand Oaks, CA: SAGE Publications.

Dahl, J., Anderson, S., \& Libarkin, J. (2005). Digging into earth science: Alternative conceptions held by K-12 teachers. Journal of Science Education, 12, 65-68.

Dawson, V., \& Carson, K. (2013). Science teachers' and senior secondary schools students' perceptions of Earth and environmental science topics. Australian Journal of Environmental Education, 29(2), 202-220.

Dodick, J., \& Orion, N. (2003). Cognitive factors affecting student understanding of geologic time. Journal of Research in Science Teaching, 40(4), 415-442.

Francek, M. (2013). A compilation and review of over 500 Geoscience misconceptions. International Journal of Science Education, 35(1), 31-64.

King, C. (2000). The Earth's mantle is solid: Teachers' misconceptions about the Earth and plate tectonics. School Science Review, 82(298), 57-64.

King, C. (2010). An analysis of misconceptions in science textbooks: Earth science in England and Wales. International Journal of Science Education, 32(5), 565-601.

Lane, R. (2009). Articulating the pedagogical content knowledge of accomplished geography teachers. Geographical Education, 22, 40-50.

Lane, R. (2011). Exploring content knowledge of experienced geography teachers. Geographical Education, 24, 51-63.

Lane, R. (2015). Experienced geography teachers' PCK of students' ideas and beliefs about learning and teaching. International Research in Geographical and Environmental Education, 24(1), 43-57.

Lane, R., \& Coutts, P. (2012). Students' alternative conceptions of tropical cyclone causes and processes. International Research in Geographical and Environmental Education, 21(3), 205-222.

Libarkin, J., \& Anderson, S. (2005). Assessment of learning in entry-level geoscience courses: Results of the geoscience concept inventory. Journal of Geoscience Education, 53(4), 394-401.

Marques, L., \& Thompson, D. (1997). Misconceptions and conceptual changes concerning continental drift and plate tectonics among Portuguese students aged 16-17. Research in Science \& Technological Education, 15(2), 195-222.

Mills, R., Tomas, L., \& Lewthwaite, B. (in press). Learning in Earth and space science: A review of conceptual change instructional approaches. International Journal of Science Education. 
Nielsen, W., \& Hoban, G. (2015). Designing a digital teaching resource to explain phases of the moon: A case study of preservice elementary teachers making a slowmation. Journal of Research in Science Teaching, 52(9), 1207-1324.

Nunally, J. (1978). Psychometric theory. New York, NY: McGraw-Hill.

Osborne, R., \& Gilbert, J. (1979). Investigating student understanding of basic physics concepts using an interview-about-instances technique. Research in Science Education, 9(1), 85-93.

Ozturk, M., \& Alkis, S. (2010). Misconceptions in geography. Geographical Education, 23(1), 54-63.

Pintrich, P., Marx, R., \& Boyle, R. (1993). Beyond cold conceptual change: The role of motivational beliefs and classroom contextual factors in the process of conceptual change. Review of Educational Research, 63(2) 167-199.

Posner, G., Strike, K., Hewson, P., \& Gertzog, W. (1982). Accommodation of a scientific conception: Towards a theory of conceptual change. Science Education, 66(2), 211227.

Reinfried, S. (2006). Conceptual change in physical geography and environmental sciences through mental model building: The example of groundwater. International Research in Geographical and Environmental Education, 15(1), 41-61.

Schubert, J. (2014). Causes, processes and consequences of "desertification": Results of a qualitative study about the conceptions of 12 and 13 year old students in Germany. International Research in Geographical and Environmental Education, 24(2), 148166.

Smith, G., \& Bermea, S. (2012). Using students' sketches to recognize alternative conceptions about plate tectonics persisting from prior instruction. Journal of Geoscience Education, 60(4), 350-359.

Steer, D., Knight, C., Owens, K., \& McConnell, D. (2005) Challenging students' ideas about Earth's interior using a model-based conceptual change approach in a large class setting. Journal of Geoscience Education, 53(4), 415-421.

Stoltman, J., Lidstone, J., \& Kidman, G. (2015). Physical geography education research: Is it relevant? International Research in Geographical and Environmental Education, 24(2), 103-104.

Treagust, D., \& Duit, R. (2008). Conceptual change: A discussion of theoretical, methodological and practical challenges for science education. Cultural Studies in Science Education, 3(2), 297-328.

Treagust, D. (1988). Development and use of diagnostic tests to evaluate students' misconceptions in science. International Journal of Science Education, 10(2), 159169.

Trundle, K., Atwood, R., \& Christopher, J. (2002). Preservice elementary teachers' conceptions of moon phases before and after instruction. Journal of Research in Science Teaching, 39(7), 633-658.

Tyson, L., Venville, G., Harrison, A., \& Treagust, D. (1997). A multidimensional framework for interpreting conceptual change events in the classroom. Science Education, 81(4) 387-404.

Ucar, S., Trundle, K., \& Krissek, L. (2011). Inquiry-based instruction with archived, online data: An intervention study with pre-service teachers. Research in Science Education, 41(2), 261-282. 